\title{
EVALUACIÓN DE UN MÉTODO DE EXTRACCIÓN Y PURIFICACIÓN DE DNA A PARTIR DE TEJIDO MUSCULAR FIJADO EN FORMALDEHIDO DE CADÁVERES NO IDENTIFICADOS
}

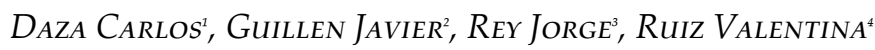 \\ ${ }^{1}$ Oficial Ejército Nacional, Biólogo, Estudiante Maestría en Ciencias Biomédicas, Universidad El Bosque. \\ Director Laboratorios Facultad de Medicina, Universidad Militar Nueva Granada, Bogotá, Colombia. \\ ${ }^{2}$ Médico, Magister en Educación, Magister en Administración en Servicios de Salud. Coordinador Laboratorio de \\ Morfología, Facultad de Medicina, Universidad Militar Nueva Granada, Bogotá, Colombia. \\ ${ }^{3}$ Odontólogo, Magister en Ciencias Biológicas, Doctor en Ciencias Biológicas. Coordinador Laboratorio de Investiga- \\ ciones Facultad de Medicina, Director Grupo BONE, Universidad Militar Nueva Granada, Bogotá, Colombia. \\ ${ }^{4}$ Estudiante programa de Medicina, Universidad Militar Nueva Granada, Bogotá, Colombia. \\ Correspondencia: labmedicina@unimilitar.edu.co \\ Recibido: Abril 30 de 2014 Aceptado: Junio 24 de 2014

\begin{abstract}
Resumen
La obtención de DNA humano en buena cantidad y alta pureza a partir de tejido muscular fijado en Formaldehido no tamponado es de suma importancia en la amplificación por la Reacción en Cadena de la Polimerasa (PCR) para su aplicación en estudios de identificación y filiación genética. En este estudio se evaluó la eficiencia del Kit QIAampR DNA FFPE TISSUE y una modificación del mismo basado en lavados con PBS y el tiempo de digestión con proteinasa K, frente a la cantidad y calidad de este ácido nucléico. Las diferencias fueron significativas entre los tiempos de acción con la proteinasa $\mathrm{K}(\mathrm{PK})$ en relación a la cantidad y en la pureza producto de los lavados del tejido muscular previa extracción. Estos resultados proporcionan una pauta para el diseño de experimentos de acuerdo con el efecto de la fijación, optimizando recursos humanos e insumos.
\end{abstract}

Palabras clave: Formaldehido, tejido muscular, proteinasa K, lavado celular.

\section{EVALUATION OF A METHOD OF EXTRACTING AND PURIFYING DNA FROM MUSCLE TISSUE FIXED IN FORMALDEHYDE UNIDENTIFIED BODIES}

\begin{abstract}
Obtaining human DNA in large quantity and high purity from muscle tissue fixed in formaldehyde unbuffered is of utmost importance in amplification by Chain Reaction (PCR) for application in identification studies and genetic affiliation. In this study, the efficiency of DNA FFPE TISSUE QIAampR Kit and a modification thereof based washes with PBS and the time of digestion with proteinase $\mathrm{K}$, compared to the amount and quality of the nucleic acid were evaluated. Differences were significant between the exposure times with proteinase $\mathrm{K}(\mathrm{PK})$ in relation to the quantity and purity of the product prior washings muscle tissue extraction. These results provide a guideline for the design of experiments according to the effect of fixing, optimizing human resources and inputs.
\end{abstract}

Keywords: Formaldehyde muscle tissue, proteinase $\mathrm{K}$, cell washing. 


\title{
AVALIAÇÃO DE UM MÉTODO DE EXTRACÇÃO E PURIFICAÇÃO DE ADN A PARTIR DE TECIDO MUSCULAR FIXADO EM FORMALDEÍDO CORPOS NÃO IDENTIFICADOS
}

\begin{abstract}
Resumo
A obtenção de DNA humano em grande quantidade e de alta pureza a partir de tecido muscular fixado em formol não tamponado é de extrema importância para a amplificação por Reacção em Cadeia (PCR), para sua aplicação em estudos de identificação e filiação genética. Neste estudo, a eficácia do kit QIAampR DNA FFPE TISSUE e uma modificação do processo por lavagens com PBS e o tempo de digestão com proteinase $\mathrm{K}$, em comparação com a quantidade e a qualidade do ácido nucléico desta base. As diferenças foram significativas entre os tempos de exposição com proteinase $\mathrm{K}$ em relação à quantidade e pureza produto das lavagens do tecido muscular extraída previamente. Estes resultados fornecem uma diretriz para o desenho de experimentos de acordo com o efeito de fixação, otimizando recursos humanos e insumos.
\end{abstract}

Palavras chave: Formaldeído, tecido muscular, proteinase K, lavagem celular.

\section{Introducción}

El Formaldehido al 37\% conocido comercialmente como Formalina, es la solución más utilizada en los laboratorios de Morfología para preservar cadáveres y piezas anatomopatológicas (1). Sin embargo, los largos periodos de tiempo en que permanecen las estructuras anatómicas promueven que el Formaldehido se transforme gradualmente en Ácido Fórmico, el cual produce entrecruzamiento (cross-linkange) entre ácidos nucléicos y proteínas; hidroliza puentes fosfodiester del DNA y modifica covalentemente el RNA por adición de grupos metilos en las bases nitrogenadas, generando problemas en la obtención de material genético óptimo para realizar posteriores estudios moleculares $(2,3,4)$. No obstante, estudios han demostrado que el tratamiento con proteinasas mejora la recuperación del DNA, ya que permite liberar los ácidos nucléicos atrapados en los complejos proteicos (5) y han tratado de mejorar la digestión del tejido mediante el aumento de la concentración de proteinasa $\mathrm{K}$, prolongación del período de digestión, y/o mediante el aumento de la temperatura de incubación $(3,6,7,8)$.

Las soluciones fijadoras de tejido sin buffer, causan por la acción del ácido una fragmentación hidrolítica de los ácidos nucléicos (3). Por consiguiente, al emplear los protocolos de extracción de DNA estándar, se obtiene generalmente pequeñas cantidades impuras $y$, a veces muy fragmentadas que no pueden ser amplificadas por la técnica de Reacción en Cadena de la Polimerasa PCR (9).
Considerando los estudios publicados, el grupo de investigación se propone evaluar la eficiencia del kit comercial de extracción QIAampR DNA FFPE TISSUE en la cantidad de DNA, la reversión de las modificaciones de las moléculas de los ácidos nucleicos y su grado de pureza a partir de tejido muscular fijado en Formaldehido al 37\%, procedente de cadáveres humanos no identificados de un laboratorio de Morfología.

\section{Materiales y Métodos}

\section{Consideraciones éticas}

La presente investigación se reglamentó con base en las consideraciones éticas colombianas soportadas en el literal a del art. 30 y el literal c del art. 8 del Decreto 2363 de 1986, el art. 46 del Decreto 2493 de 2004, la Ley 9 de 1979, el art. 2 Ley 73 de 1988 (EXEQUIBLE por la Corte Constitucional por SC-933- 07 MP, Jaime Araujo Rentería), la Resolución 2640 de 2005, la Resolución 00567 de 2012 del Instituto de Medicina Legal y Ciencias Forenses y la Resolución 001012 de 2012 del Ministerio de Salud y Protección Social.

\section{Muestras anatómicas}

A partir de 12 cadáveres de humanos no identificados, localizados en el Laboratorio de Morfología de la Facultad de Medicina en la Universidad Militar Nueva Granada (Bogotá, Colombia); se recolectaron doce muestras de 0,5 $\mathrm{cm}^{2}$ de diámetro del músculo supinador, fijados por más 


\section{EVALUACIÓN DE UN MÉTODO DE EXTRACCIÓN Y PURIFICACIÓN DE DNA A PARTIR DE TEJIDO MUSCULAR FIJADO EN FORMALDEHIDO DE CADÁVERES NO IDENTIFICADOS}

de cinco años en Formaldehido al 37\%; posterior a este procedimiento el grupo procedió a realizar 5 lavados de cada tejido muscular con $700 \mu \mathrm{L}$ de Buffer PBS (Buffer Fosfato Salino) pH 7.4 durante 1 minuto y luego se maceraron en mortero cerámico.

\section{Digestión del tejido muscular}

Se tomaron alícuotas de $300 \mu \mathrm{L}$ por cada maceración homogenizada en tubos Eppendorf de $1.5 \mathrm{ml}$ y se centrifugaron a $14.000 \mathrm{rpm}$ por 2 minutos, eliminando el sobrenadante.

Los botones celulares fueron tratados de acuerdo al protocolo estandarizado del kit comercial que establece resuspender el pelet en $180 \mu \mathrm{L}$ de Buffer ATL (Animal Tissue Lysis - Cat. 69504 qiagen $^{\circledR}$ ) y realizar la lisis orgánica con $20 \mu \mathrm{L}$ de la enzima proteinasa $\mathrm{K}$ por 1 hora a $56 \mathrm{C}$ con agitación mecánica a 100 rpm.

Otro método fue el tratamiento modificado del protocolo del kit comercial, que se diferenció por la realización de 3 lavados a los botones celulares con $500 \mu \mathrm{L}$ de agua ultrapura seguidos por centrifugaciones a $14.000 \mathrm{rpm}$ de 2 minutos para precipitar el botón celular y realizar la lisis orgánica con la enzima proteinasa $\mathrm{K}$ por 24 horas a 56 C con agitación mecánica a $100 \mathrm{rpm}$ recomendado por Rivero y cols (10).

Por último, en los dos métodos se efectuó una incubación de las muestras a $90{ }^{\circ} \mathrm{C}$ durante 1 hora para revertir los entrecruzamientos en el DNA producidos por el Formaldehído e inactivar la acción enzimática (2-4).

\section{Extracción del ADN}

La etapa de extracción del DNA, se realizó con $200 \mu \mathrm{L}$ de Buffer AL (contiene Clorhidrato de guanidina - Cat. 69504 Qiagen $^{\circledR}$ ) y $200 \mu \mathrm{L}$ de Etanol absoluto, mezclados previamente y homogenizados con vortex. El lisado se transfirió a columnas QIAamp MinElute con tubos colectores de $2 \mathrm{ml}$. Se centrifugo a $8.000 \mathrm{rpm}$ por 1 minuto y se transfirieron las columnas a nuevos tubos colectores de $2 \mathrm{ml}$ del kit descartando los tubos colectores que contenían el eluido.

En la etapa de lavado se añadieron $500 \mu \mathrm{L}$ de Buffer AW1 (contiene Clorhidrato de guanidina - Cat. 69504 QIAGEN $^{\circledR}$ ), se centrifugo a $8.000 \mathrm{rpm}$ por 1 minuto y se transfirió las columnas a nuevos tubos colectores de 2 $\mathrm{ml}$ del kit descartando los tubos colectores con el eluido. Seguido se añadieron $500 \mu \mathrm{L}$ de Buffer AW2 (compuesto esencialmente por Etanol 70\% - Cat. 69504 Qiagen $^{\circledR}$ ), se centrifugo a $8.000 \mathrm{rpm}$ por 1 minuto y se trasladaron las columnas a nuevos tubos colectores de $2 \mathrm{ml}$ del kit, eliminando los tubos colectores que contenían el eluido, se centrifugo a $14.000 \mathrm{rpm}$ por 3 minutos y se transfirieron las columnas a tubos Eppendorf de $1.5 \mathrm{ml}$ no suministrados con el kit y se descartaron los tubos colectores que contenían el eluido de la columna.

Finalmente en la etapa de elución se añadieron $50 \mu \mathrm{L}$ de Buffer ATE (Tris-HCl, Edta, Azida sódica - Cat. 69504 QIAGEN ${ }^{\circledR}$ ), seguido por una incubación a temperatura ambiente por 5 minutos y centrifugación a $14.000 \mathrm{rpm}$ por 2 minutos donde se descartaron las columnas y se preservó el eluido. Luego se almacenaron las muestras a -20 C hasta su cuantificación.

\section{Cuantificación y pureza del DNA}

La cuantificación del DNA fue determinada por espectrofotometría (NanoDrop 100) calculada a través de la absorbancia a $260 \mathrm{~nm}$ (A260) y la pureza se obtuvo mediante la relación A260/A280 y A260/A230 empleado por Sambrook y cols (11).

\section{Visualización del DNA}

Se sembró en un gel de agarosa al 1.5\% teñido con SYBR green en buffer TBE (Tris-borato-Edta) $1 \mathrm{X}, 7 \mu \mathrm{L}$ de las 10 muestras con mayor concentración de DNA para su corrido electroforético por 90 minutos y se visualizó el ácido nucléico bajo luz ultravioleta de equipo transiluminador en cuarto oscuro $(1,12)$.

\section{Resultados}

\section{La cantidad de DNA extraído es mayor al prolongar la acción enzimática de la Proteinasa K.}

El DNA genómico que se extrajo con el Kit QIAampR DNA FFPE TISSUE sin modificar proveyó una concentración con un mínimo $6.05 \mathrm{ng} / \mu \mathrm{L}$ y un máximo $12.05 \mathrm{ng} / \mu \mathrm{L}$ para un rango final de $6.0 \mathrm{ng} / \mu \mathrm{L}$. Sin embargo, cuando las muestras fueron tratadas con el protocolo modificado, se obtuvo una mayor concentración de DNA con un mínimo de $6.9 \mathrm{ng} / \mu \mathrm{L}$ y un máximo de $65.65 \mathrm{ng} / \mu \mathrm{L}$ con un rango de $58.75 \mathrm{ng} / \mu \mathrm{L}$. También se observó una media de 8.56 $\mathrm{ng} / \mu \mathrm{L}$ cuando se realizó la digestión con la enzima PK por 1 hora, con una desviación estándar de 2.14 que refleja la homogeneidad de las cantidades de DNA en todas las muestras extraídas con el protocolo comercial. Sin embargo, cuando las muestras fueron digestadas con la enzima 
PK toda la noche, se obtuvo una media de $20.51 \mathrm{ng} / \mu \mathrm{L}$ con una desviación estándar de 16.99 que representa una moderada heterogeneidad en las cantidades de DNA extraído con el protocolo modificado (tabla 1). Por tanto, al comparar los protocolos comercial y modificado en relación a la cantidad de DNA (figura 1), se observó una diferencia estadística significativa entre los dos $(P=0.0244)$.

Los valores de pureza del DNA mejoran con los lavados celulares previos al procedimiento de extracción.

Los valores de la relación A260/A280 del DNA obtenido con el protocolo del kit comercial QIAampR DNA FFPE TISSUE mostro una pureza mínima de - 18.89 y una máxima de
10.81 con un rango de 29.71. Por el contrario, con el protocolo modificado del kit se obtuvo una pureza con un mínimo de -2.59 y un máximo de 4.89 con un rango de 7.48. La absorbancia 260/280 con el protocolo estandarizado del kit comercial mostro un promedio de 1.8 y con el protocolo modificado de 2.55 y una heterogeneidad de los valores de pureza para ambos (figuras 2 y 3 ), pero más significativa con el tratamiento de 1 hora con la enzima PK (tabla 2).

Los resultados en el sesgo estandarizado y/o la curtosis estandarizada para los valores de pureza DO 260/280 se encontraron fuera del rango de $-2 \mathrm{a}+2$ para los niveles de tratamiento con la enzima PK que indica una no normalidad significativa en los datos, el cual viola el supuesto de que los datos provenían de distribuciones normales (tabla 3).

Tabla 1. Resumen Estadístico para Concentración DNA.

\begin{tabular}{|l|c|c|c|c|c|c|c|}
\hline Tratamiento & Recuento & Promedio & $\begin{array}{c}\text { Desviación } \\
\text { estándar }\end{array}$ & $\begin{array}{c}\text { Coeficiente de } \\
\text { variación }\end{array}$ & Mínimo & Máximo & Rango \\
\hline 1h PK & 12 & 8,5625 & 2,14011 & $24,9939 \%$ & 6,05 & 12,05 & 6,0 \\
\hline ON PK & 12 & 20,5125 & 16,9985 & $82,8691 \%$ & 6,9 & 65,65 & 58,75 \\
\hline Total & 24 & 14,5375 & 13,328 & $91,6804 \%$ & 6,05 & 65,65 & 59,6 \\
\hline
\end{tabular}

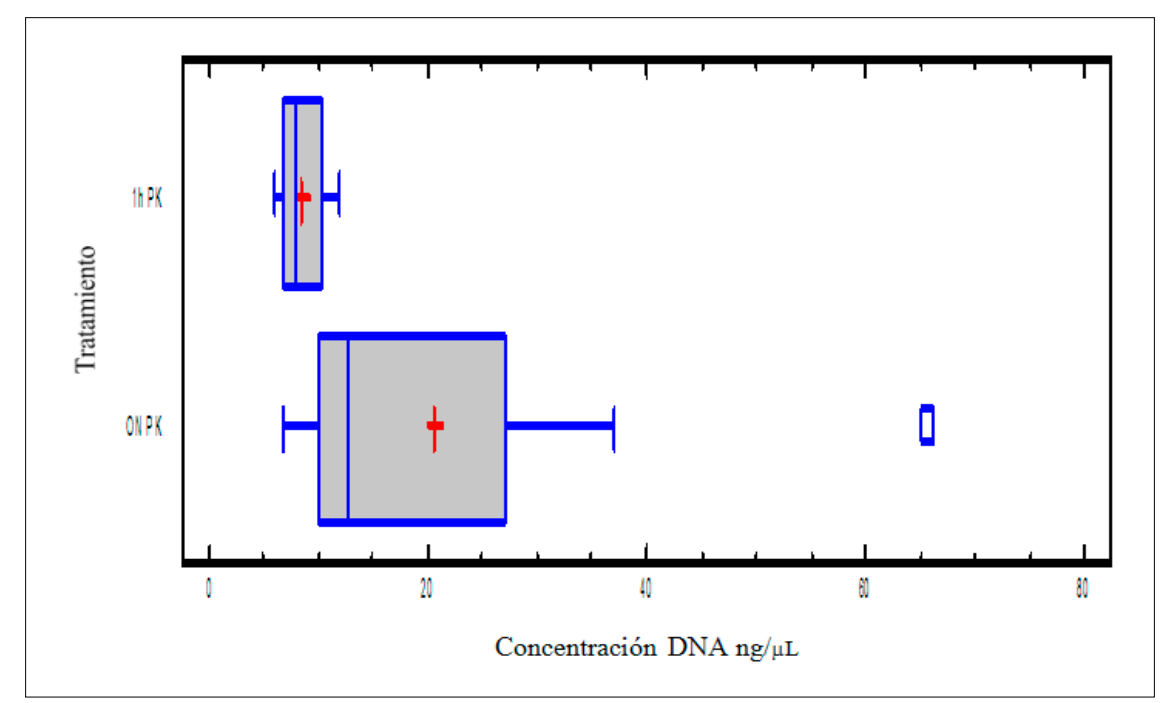

Figura 1. Relación de la concentración de DNA en ng/ $\mu \mathrm{L}$ obtenida con los dos tratamientos con la enzima $P K$.

Tabla 2. Resumen Estadístico de la pureza OD 260/ 280.

\begin{tabular}{|l|c|c|c|c|c|c|c|}
\hline \multicolumn{1}{|c|}{ Tratamiento } & Recuento & Promedio & $\begin{array}{c}\text { Desviación } \\
\text { estándar }\end{array}$ & $\begin{array}{c}\text { Coeficiente de } \\
\text { variación }\end{array}$ & Mínimo & Máximo & Rango \\
\hline 1hPK & 12 & 1.80125 & 8.6238 & $478.767 \%$ & -18.895 & 10.81 & 29.705 \\
\hline ONPK & 12 & 2.54833 & 1.9042 & $74.7233 \%$ & -2.585 & 4.89 & 7.475 \\
\hline Total & 24 & 2.17479 & 6.11947 & $281.382 \%$ & -18.895 & 10.81 & 29.705 \\
\hline
\end{tabular}




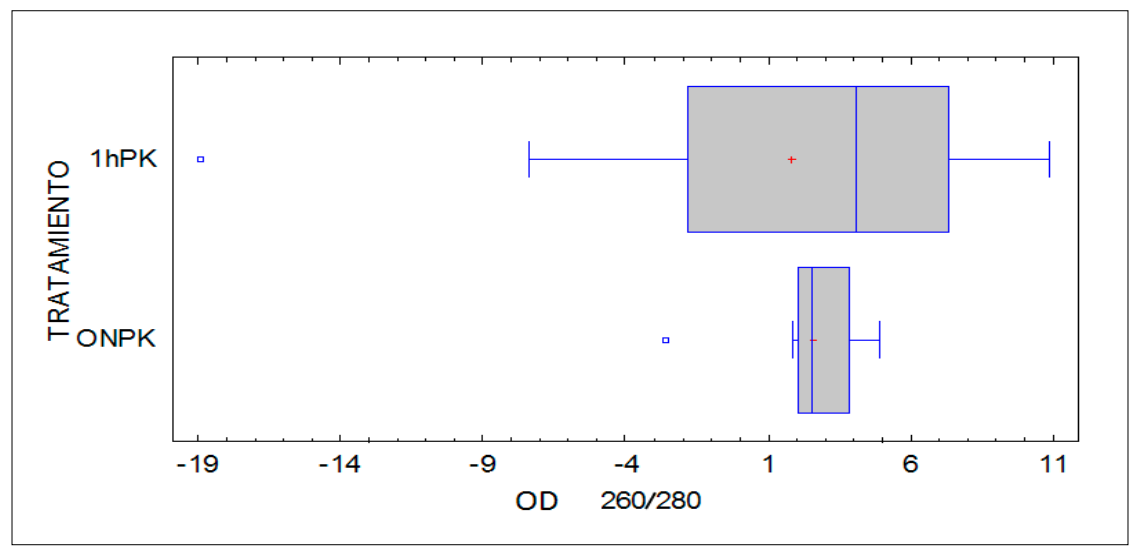

Figura 2. Relación de la pureza OD 260/280 con los tratamientos de la enzima PK.

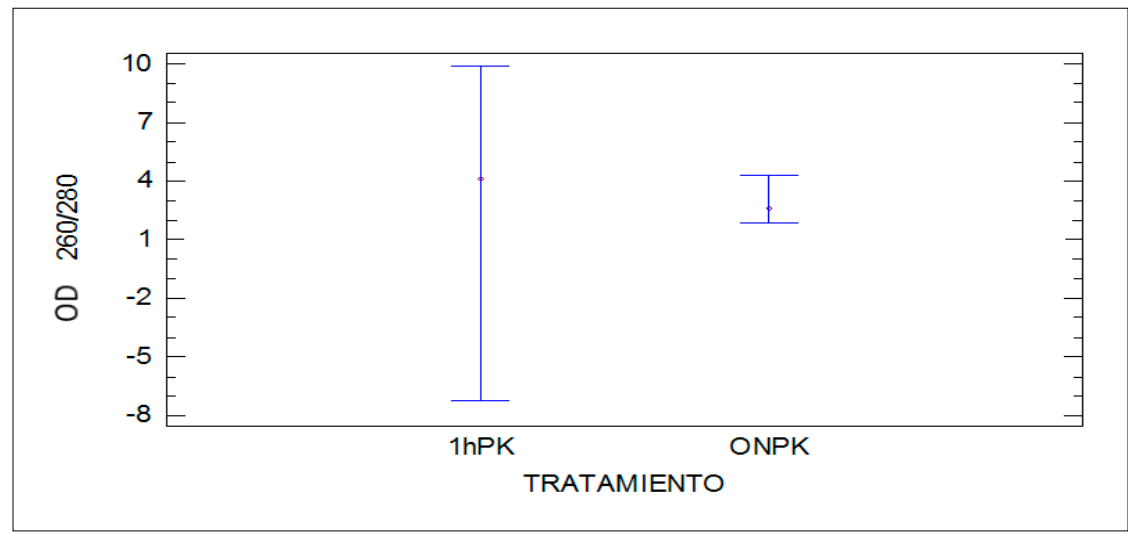

Figura 3. Gráfico de las medianas con intervalo de confianza del 95\% de la pureza OD 260/280 para los tratamientos con la enzima $P K$

Por tanto, se empleó como alternativa estadística la prueba de Kruskal-Wallis para comparar las medianas de los dos tratamientos en lugar de las medias, la cual demostró una diferencia estadísticamente significativa $P=0.225$ (tabla 4).

Tabla 3. Sesgo estandarizado y curtosis estandarizada para $O D$ 260/280.

\begin{tabular}{|l|c|c|}
\hline Tratamiento & $\begin{array}{c}\text { Sesgo } \\
\text { estandarizado }\end{array}$ & $\begin{array}{c}\text { Curtosis } \\
\text { estandarizada }\end{array}$ \\
\hline $1 \mathrm{hPK}$ & -1.99796 & 1.37495 \\
\hline ONPK & -2.49952 & 3.4487 \\
\hline Total & -3.84547 & 5.56511 \\
\hline
\end{tabular}

Tabla 4. Prueba de Kruskal-Wallis para OD 260/280.

\begin{tabular}{|l|c|c|}
\hline Tratamiento & Tamaño muestra & Rango promedio \\
\hline $1 \mathrm{hPK}$ & 12 & 14.25 \\
\hline ONPK & 12 & 10.75 \\
\hline
\end{tabular}

La relación A260/A230 presento un mínimo y un máximo de pureza de 0.07 a 0.11 con un rango de 0.05 para el protocolo del kit comercial. En contraste, con el protocolo modificado se observó un mínimo de 0.06 y un máximo de 0.47 cuyo rango fue de 0.4 . El promedio de pureza con el protocolo comercial fue de 0.09 en comparación con el protocolo modificado que fue de 0.18 que al ser correlacionado con el coeficiente de variación, se evidencio una moderada y marcada heterogeneidad de la pureza respectivamente (tabla 5).

La pureza del DNA determinado con DO 260/230 en un intervalo de confianza del 95\% para los dos tratamientos, permitió inferir que las medias de los dos tratamientos no eran iguales (figuras 4 y 5) y que por tanto existía una diferencia estadísticamente significativa con una $P=0.026$. En consecuencia, al no cumplirse el supuesto de igualdad de las varianzas se empleó la prueba estadística de Kruskal-Wallis para comparar las medianas donde se observó una diferencia estadística significativa con una $P=0.005$ (tabla 6). 
Tabla 5. Resumen Estadístico para la pureza OD O260 /230.

\begin{tabular}{|l|c|c|c|c|c|c|c|}
\hline \multicolumn{1}{|c|}{ Tratamiento } & Recuento & Promedio & $\begin{array}{c}\text { Desviación } \\
\text { estándar }\end{array}$ & $\begin{array}{c}\text { Coeficiente de } \\
\text { variación }\end{array}$ & Mínimo & Máximo & Rango \\
\hline 1hPK & 12 & 0,0870833 & 0,0157333 & $18,067 \%$ & 0,065 & 0,11 & 0,045 \\
\hline ONPK & 12 & 0,183333 & 0,123846 & $67,5525 \%$ & 0,06 & 0,465 & 0,405 \\
\hline Total & 24 & 0,135208 & 0,0993509 & $73,4799 \%$ & 0,06 & 0,465 & 0,405 \\
\hline
\end{tabular}

Tabla 6. Prueba de Kruskal-Wallis para OD 260/230.

\begin{tabular}{|l|c|c|}
\hline \multicolumn{1}{|c|}{ Tratamiento } & Tamaño muestra & Rango promedio \\
\hline $1 \mathrm{hPK}$ & 12 & 8,45833 \\
\hline ONPK & 12 & 16,5417 \\
\hline
\end{tabular}

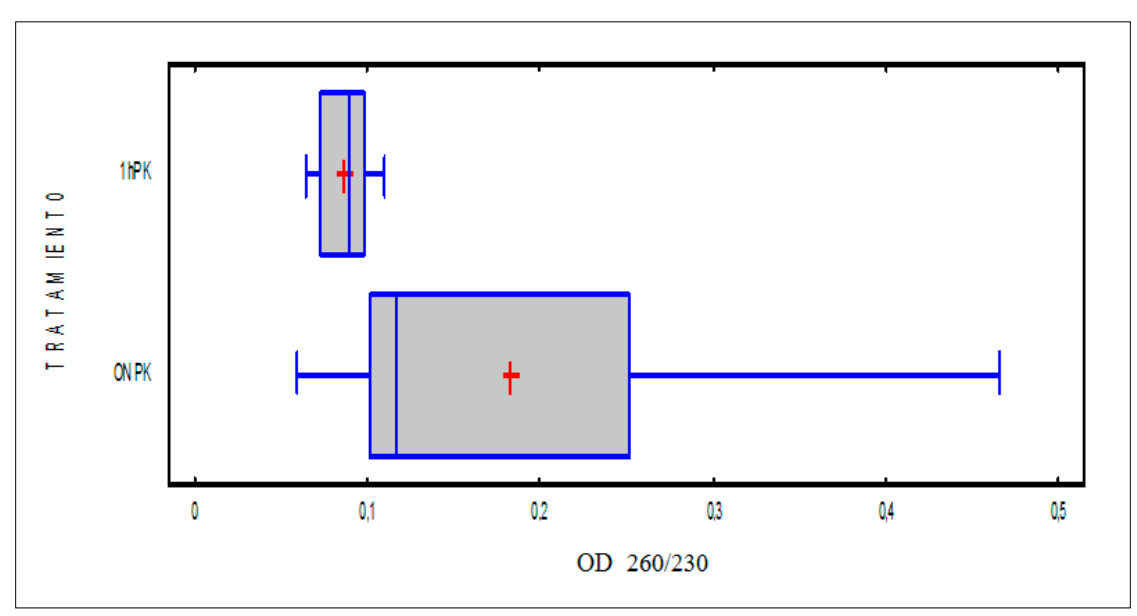

Figura 4. Relación de la pureza OD 260/230 con los tratamientos de la enzima PK.

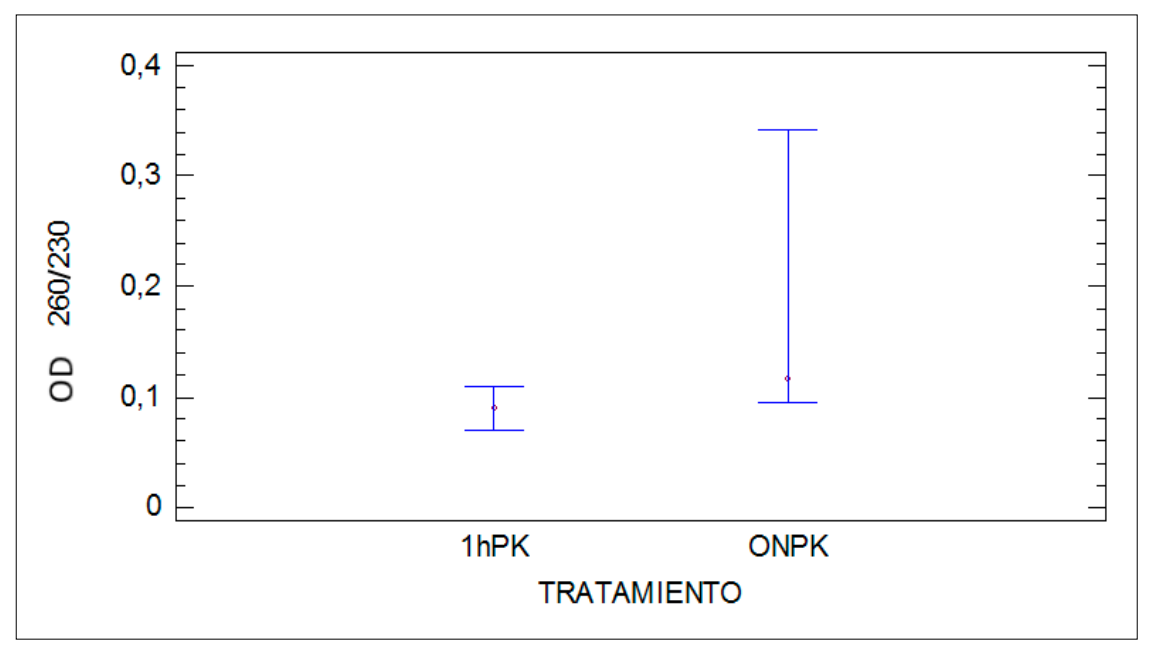

Figura 5. Gráfico de las medianas con intervalos de confianza del 95\% de la pureza OD 260/230 para los tratamientos con la enzima $P K$. 


\section{EVALUACIÓN DE UN MÉTODO DE EXTRACCIÓN Y PURIFICACIÓN DE DNA A PARTIR DE TEJIDO MUSCULAR FIJADO EN FormaLDEHIDO dE CADÁVERES NO IDENTIFICADOS}

El DNA genómico extraído con el Kit QIAampR DNA FFPE TISSUE sin modificar no genera un patrón electroforético de corrido en las muestras analizadas.

La siembra de la mayor concentración de DNA genómico de las muestras, se realizó en un gel de agarosa al $1.5 \%$, el cual no revelo teñido genómico con el protocolo estandarizado del kit comercial (bandas 3A1, 7A, 8A, 10A, 12A1). Sin embargo, con el protocolo modificado se observó un patrón de electroforesis caracterizado por bandas homogéneas (bandas 1B1, 5B, 7B1, 10B, 11B). En este sentido, el control positivo $\left(\mathrm{C}^{+}\right)$presento un DNA de alto peso molecular observado en la parte superior del pozo de carga (figura 6).

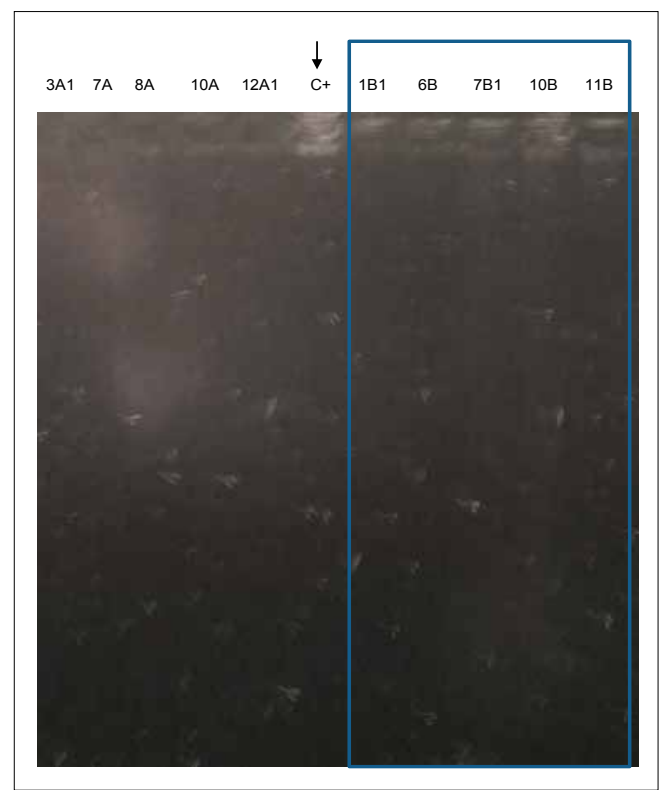

Figura 6. Fotografía gel de agarosa $1.5 \%$ donde se evidencia el contraste en los resultados de extracción de DNA genómico con el Kit QIAampR DNA FFPE TISSUE sin modificar a la izquierda y con modificaciones a la derecha en el recuadro azul.

\section{Discusión}

Actualmente, los tejidos fijados en Formalina y embebidos en parafina FFPE se utilizan cada vez más en los análisis moleculares tanto en laboratorios de patología e investigación. La eliminación de la cera de parafina que protege al tejido y la extracción de una buena cantidad de DNA no degradado, son los principales obstáculos en el trabajo con esta clase de muestras (13). En los últimos años, los métodos y protocolos para el aislamiento ácidos de nucléicos a partir de tejidos FFPE han mejorado enormemente $(3,4,14)$.
Nuestros resultados demuestran que al ampliar el tiempo de acción enzimática de la PK de 1 h a 24 h, aumenta hasta en cuatro veces la concentración de DNA que se extrajo con el kit comercial QIAampR DNA FFPE TISSUE ya que muy probablemente libera los complejos proteicos unidos a este ácido nucléico $(6,14,15)$. También se observa una heterogeneidad en la concentración de DNA en los dos protocolos, posiblemente debido a diferencias en la cantidad de células que se tomaron con las alícuotas, luego de ser maceradas las muestras de músculo supinador.

Sin embargo, es baja la cantidad de DNA que se obtuvo con el presente kit comercial debido quizás al extenso tiempo de exposición de los componentes anatómicos en el Formaldehido y a la falta del empleo de buffer alcalinos en el protocolo de extracción como lo reportado por Campos y Gilbert (16).

La pureza del DNA que se obtuvo al emplear el protocolo estandarizado del kit comercial evidencio una marcada contaminación en todas las muestras tanto por proteínas como con Formol, con una mayor tendencia a la presencia de Formol lo cual concuerda ampliamente con otros estudios publicados $(17,18)$. En contraste, con el protocolo modificado del kit en el que se realizaron lavados con PBS a los pellet celulares, la contaminación con Formol estuvo presente en casi todas las muestras pero con el atenuante de que los valores de pureza estaban más cercanos al rango ideal (19). Las diferencias en las purezas de DNA observadas en algunos casos entre las muestras y sus réplicas se deben al parecer por la misma razón de las diferencias en la concentración del DNA, en cuanto a lo relacionado con la cantidad de tejido depositado al inicio del procedimiento.

El corrido del DNA en el gel de agarosa y su visualización bajo luz ultravioleta, revelo el bajo rendimiento en la extracción con el protocolo del kit comercial. Por el contrario, con el protocolo modificado se evidencio un tenue bandeo homogéneo que nos permite determinar que el material genético está presente en poca cantidad y que no se encuentra degradado.

En conclusión, aunque es un reto extraer DNA de buena cantidad y gran tamaño a partir de tejidos fijados en Formaldehido no tamponado, la técnica de extracción con el Kit QIAampR DNA FFPE TISSUE modificado en este estudio permitió obtener DNA en una cantidad y calidad que podría ser apropiado para estudios posteriores de amplificación por PCR convencional (20). 


\section{Referencias}

1. Sánchez J. Exploración de un método para la inactivación de Formaldehido en el anfiteatro de la Facultad de Salud de la Universidad del Valle [Tesis]. Cali (Colombia): Universidad del Valle; 2011.

2. Blow N.Tissue preparation: tissue issues. $\mathrm{Na}$ ture. 2007;448(7156):959-63.

3. Gilbert MT, Haselkorn T, Bunce M, Sanchez JJ, Lucas $\mathrm{SB}$, Jewell LD, Van Marck E, Worobey M. The isolation of nucleic acids from fixed, paraffinembedded tissues-which methods are useful when? PLoS One. 2007;2(6):e537.

4. Turashvili G, Yang W, McKinney S, Kalloger S, Gale N, Ng Y, Chow K, Bell L, Lorette J, Carrier M, Luk M, Aparicio S, Huntsman D, Yip S.Nucleic acid quantity and quality from paraffin blocks: defining optimal fixation, processing and DNA/ RNA extraction techniques. Exp Mol Pathol. 2012;92(1):33-43.

5. Díaz-Cano SJ, Brady SP. DNA extraction from formalin-fixed, paraffin-embedded tissues: protein digestion as a limiting step for retrieval of high-quality DNA. Diagn Mol Pathol. 1997;6(6):342-6.

6. Duval K, Aubin RA, Elliott J, Gorn-Hondermann I, Birnboim HC, Jonker D, Fourney RM, Frégeau CJ. Optimized manual and automated recovery of amplifiable DNA from tissues preserved in buffered formalin and alcoholbased fixative Forensic Sci Int Genet. 2010;4(2):80-8.

7. Santos S, Sá D, Bastos E, Guedes-Pinto H, Gut I, Gärtner F, Chaves R. An efficient protocol for genomic DNA extraction from formalin-fixed paraffinembedded Tissues. Res Vet Sci. 2009;86(3):421-6.

8. Duval K, Aubin RA, Elliott J, Gorn-Hondermann I, Birnboim HC, Jonker D, Fourney RM, Frégeau CJ. Optimized manual and automated recovery of amplifiable DNA from tissues preserved in buffered formalin and alcoholbased fixative, Forensic Sci Int Genet. 2010;4(2):80-8.

9. Paireder S, Werner B, Bailer J, Werther W, Schmid E, Patzak B, et al. Comparison of protocols for DNA extraction from long term preserved formalin fixed tissues. Anal Biochem. 2013;439(2):152-60.
10. Rivero ER, Neves AC, Silva-Valenzuela MG, Sousa SO, Nunes FD. Simple salting-out method for DNA extraction from formalin-fixed, paraffin-embedded tissues. Pathology - Research and Practice. 2006; 202(7): 523-9.

11. Sambrook J, Fritsch EF, Maniatis T. Molecular Cloning: A Laboratory Manual. 2nd Ed.New York. Cold Spring Harbor. 1989; 9.14-9.19.

12. Weiss AT, Delcour NM, Meyer A, Klopfleisch R. Efficient and Cost-Effective Extraction of Genomic DNA From Formalin-Fixed and Paraffin-Embedded Tissues. Vet Pathol. 2011; 48(4): 834-8.

13. Okello JB, Zurek J, Devault AM, Kuch M, Okwi AL, Sewankambo NK, et al. Comparison of methods in the recovery of nucleic acids from archival formalin-fixed paraffin-embedded autopsy tissues. Anal Biochem. 2010;400(1):110-7.

14. Regan JF, Furtado MR, Brevnov MG, Jordan JA. A sample extraction method for faster, more sensitive PCR-based detection of pathogens in blood culture. J Mol Diagn. 2012;14(2):120-9.

15. Sam SS, Lebel KA, Bissaillon CL, Tafe LJ, Tsongalis GJ, Lefferts JA. Automation of genomic DNA isolation from formalin-fixed, paraffin embedded tissues. Pathol Res Pract. 2012;208(12):705-7.

16. Campos PF, Gilbert TM. DNA extraction from formalin-fixed material. Methods Mol Biol. 2012;840:81-5.

17. Srinivasan M, Sedmak D, Jewell S. Effect of fixatives and tissue processing on the content and integrity nucleic acids. Am J Pathol 2002; 161: 1961-71.

18. García P, Benavente F, Melo A, Roa I, Roa JC. Efecto de la fijación en la calidad del ADN: estudio controlado con cinco fijadores. Rev Esp Patol. 2006; 39(3): 175-9.

19. Huijsmans CJ, Damen J, van der Linden JC, Savelkoul $\mathrm{PH}$, Hermans $\mathrm{MH}$. Comparative analysis of four methods to extract DNA from paraffin-embedded tissues: effect on downstream molecular applications. BMC Res Notes. 2010;3:239.

20. Baena JA, Ramos AJ, Gómez CJ, Gómez DE. Comparación de métodos de extracción de ADN en tejidos parafinados y utilidad para amplificación por PCR. Revista Colombiana de Biotecnología. 2013; 15(1):172-9. 